\title{
Teaching And Learning: Five Women's Stories Of Leadership In Higher Education
}

Joane W. McKay, (E-mail: jmckay@stcloudst.edu), St. Cloud State University

Nancy Bacharach, (E-mail: nlbacharach@stcloudstate.edu), St. Cloud State University

Robin Hasslen, (E-mail: rchasslen@stcloudstate.edu), St. Cloud State University

Teresa W. Heck, (E-mail: twheck@stcloudstate.edu), St. Cloud State University

Gayla Holmgren, (E-mail: gayla.holmgren@stcloud.k12.mn.us), St. Cloud School District \#742

\begin{abstract}
Women in leadership provide a different voice. Five women's stories of leadership in education are told. From Deans to Department Chairs and Public School Administrators-all reflect on leadership journeys.
\end{abstract}

\section{Introduction}

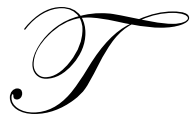

he issue of women in leadership has long been at the forefront of discussions among educators and policy makers. Donna Shalala, President of the University of Miami and a veteran of five major positions over the last 30 years, is the focus of an article in the March, 2003, issue of Women in Higher Education that suggested, "One of the tendencies keeping women from ruling the world (or at least the academy) is a reluctance to take a job unless they are at least 125\% qualified for it" (Women in Higher Education, 2003 , p. 1). As early as 1929 Virginia Wolf observed, "It is obvious that the values of women differ very often from the values which have been made by the other sex" (1929, p. 76). Gilligan's landmark work, In A Different Voice (1982) concluded that, "As we have listened for centuries to the voices of men and the theories of development that their experience informs, so we have come more recently to notice not only the silence of women but the difficulty in hearing what they say when they speak" (p. 173). In addition to these historic voices, the reality exists that women's journey in leadership in higher education is a path that has few guideposts and even fewer guides.

Women in leadership provide a different voice and exemplify different methods of communication and collaboration across disciplines, in schools and community, and in higher education. The potential for growth is realized as each leader works collaboratively through innovative programming, pain-filled conversation, and the changing demographics in which each leader works. Nevertheless, one guidepost appears consistent through each leadership story - the role of leadership in higher education is incredibly complex and interdependent on the relationships developed.

The leadership literature is complete with the challenges for leadership. Perhaps the most often stated need is, "Leaders need to have vision." Sample (2002) in The Contrarian's Guide to Leadership contended that "creative imagination, which relates to the ability to think free, may in the end be every bit as important as vision" (p. 17). Students of leadership theory have maintained that leadership is an art, not a science (DePree, 1989). DePree stated that, "Leadership is an art, something to be learned over time, not simply by reading books" (p. 3). Others have suggested that effective management may be a science. Nevertheless, Sample concluded:

The leader whose thinking is constrained with well-worn ruts, who is completely governed by established passions and prejudices, who is incapable of thinking either gray or free, and who can't even appropriate the creative imagination and fresh ideas of those around him, is as anachronistic and ineffective as the dinosaur. (p. 19) 
Artist, scientist, or dinosaur, the leader in a college or university in the 21 st century is painfully aware that there are exemplary practices and behaviors that leaders use to get extraordinary things done in organizations.

This paper presents five women's stories of leadership each from an individual perspective. Included are the voices of a Dean of a College of Education, an Associate Dean of a College of Education, a Department Chair of Child and Family Studies, the Director of Clinical Experiences in a College of Education, and an Assistant Superintendent of a local school district. All reflect on their leadership journey, their mentor or role model, their greatest challenge in their current position, their success and the lessons learned.

\section{Overview}

The purpose of this paper is to examine three major concepts about women in leadership.

1. To provide a background about leaders who care and make a difference;

2. To examine the leadership principles that apply in a specific context;

3. To identify partnership as leadership for today's leaders.

\section{Leaders Who Care and Make a Difference}

Kouzes and Posner (1987), in The Leadership Challenge, analyzed what they defined as personal best leadership and concluded that there are essentially five fundamental practices and ten behaviors in exemplary leadership. The five practices are: (a) leaders challenge the process; (b) leaders inspire a shared vision; (c) leaders enable others to act; (d) leaders model the way; (e) leaders encourage the heart (pp. 280-281). As each of the practices is examined, a profile of a transformational leader begins to emerge. The transformational leader inspires others to excel, gives individual consideration to others, and stimulates people to think in new ways. For example, when a leader challenges the process, the leader experiments and takes risks. When speaking of a shared vision, the leader envisions the future and dreams about what the organization can become. Furthermore, the leader who enables others to act knows the benefit of fostering collaboration and building spirited teams. Key to action is the leader's ability to make each person feel capable and powerful. Perhaps there is no stronger characteristic than the leader's ability to be a role model and set an example for others. Finally, leaders who encourage the heart recognize that, "getting extraordinary things done in organizations is hard work so leaders celebrate accomplishments. They make everyone feel like heroes" (Kouzes \& Posner, 1987, p. 280). The paramount question for this paper is, "How do leaders learn these practices?"

\section{Leadership Principles That Apply in a Specific Context}

Zimpher (1995), in The Wizards of Odds: Leadership Journeys of Education Deans, suggested there are certain leadership principles that must be followed if you are to be a good, cooperative citizen in a competitive environment that generally characterizes a dean's role in higher education. Zimpher outlined six basic principles that have been guideposts for her in her role as Dean of the College of Education at Ohio State University. They are:

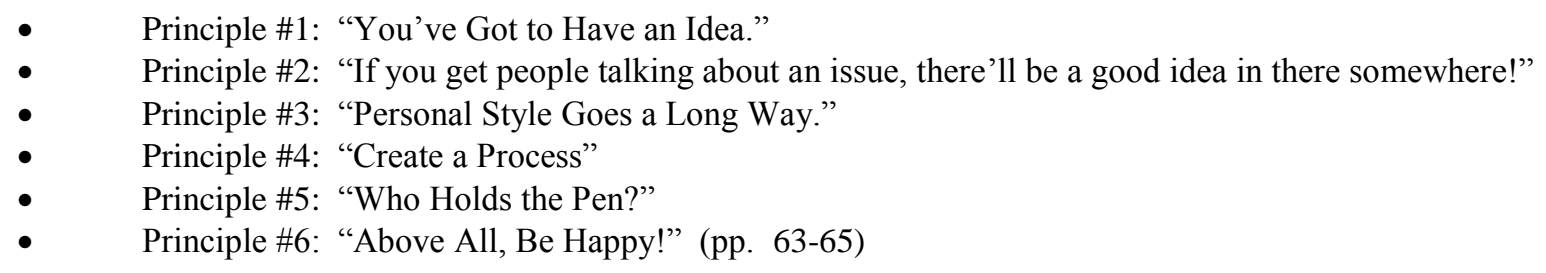

In examining the six principles, the leader recognizes that each principle gives rise to a discussion of the conditions that appear to enable or mitigate against achieving goals that leaders establish. And, again for this paper, each leader is self-critical and modest about her accomplishments so the question becomes again, "how did they learn these principles?" 


\section{Partnership as Leadership for Today's Leaders}

Lee Boman and Terrence E. Deal are two pioneers in leadership theory as well as organizational management. In one of their recent texts, Leading with Soul, (2001) Boman and Deal stated, "Leaders who have lost touch with their own souls, who are confused and uncertain about their core values and beliefs, inevitably lose their way or sound an uncertain trumpet" (p. 11). Russ Moxley's 1999 book, Leadership and Spirit: Breathing New Vitality into Individuals and Organizations, speaks to women in higher education. When individuals weave together leadership and spirit, Moxley believes, we practice leadership "that elevates the spirit, honors the whole self, and encourages us to use all our energies in the activity of leadership" (p. 3). Moxley explained "partnership as leadership" by contrasting it with a common model, the "executive-as-leader," in which leadership comes from an individual and the buck stops at the top. The women who describe their stories of leadership at a large university and local school district in the Midwest may have intuitively and knowingly relied upon the leadership theories described in these opening paragraphs. However, the substance of the paper is each individual's story in answer to the following questions:

1. When and how did my leadership journey begin?

2. Who was my mentor or role model?

3. What has been my greatest challenge in my current position?

4. What is my best success story?

5. What lessons have I learned that I would provide to other leaders?

6.

These are their stories.

\section{A Dean's Story}

I jokingly tell my colleagues, I should read a book on leadership; yet when I think of my personal leadership journey, I know it has not been book-learned. Rather, leadership for me has been a series of experiences where I was called to lead, expected to lead, directed to lead, and compelled to lead.

My mother had a strong influence on my view of women in leadership. She was an organizer and a doer in the community serving on the school board long before other women were elected, organizing rural communities in fund raising for a local hospital or taking on the Pentagon when the military decided to place a minuteman missile in our wheat field. All were actions that took organizational skills and commitment. She never wavered. She set the goal and moved ahead. I do not think it ever occurred to her that she was a woman ahead of her time. She simply saw a need, made a plan to address that need, and did not stop until the goal was accomplished. I assumed that was how other women of her generation responded.

It was not until I enrolled in a small liberal arts college in the Midwest that I heard people discussing the attributes of leadership. In that setting I recall vividly the first time anyone ever called me a leader. I was giving a campaign speech for a friend to become the dorm president (they were called dorms back then). After the speech, there was much applause and a person in the audience announced, "You seem like a real leader. Let's elect you." The next day, the secret ballot election revealed that I had been elected the East Hall President. It was that unlikely beginning that introduced me to the Dean of Women Students. This remarkable woman had the rare gift to make you believe that everything was possible and you only needed a plan for achieving your goals. She was a task master, a perfectionist, a nurturer, and a role model. Above all, she liked me. She had a profound influence on my life and encouraged me to step outside the box. Run for Student President. Did it matter that the College had never had a woman student body president? Try for a Woodrow Wilson Fellowship. Was there a reason that women were not being awarded? This mentor was always there encouraging and presenting new possibilities. And when I failed, as we all do at times, she was there to strategize with you about what you might do better the next time.

Success stories are hard to identify in leadership positions because often there is so little time to reflect. I think often about the concept of "on my watch" and I know that I must always be mindful of being responsible for those things that happen "on my watch." I tend to see the creative side of issues and my solutions tend to be just a 
little loose or provocative. So when I think of my success stories over the 7 years that I have served as Dean of the College of Education in this comprehensive university in the Midwest, I am mindful of the tremendously competent people who have stayed with me in the good times and in the bad to change who we are. We have changed-we are nationally known, we are major players in teacher preparation, we are leaders in social justice and diversity issues. We have technology to support our work. We are a successful NCATE pilot site. These are, however, simply lists that may or may not be perceived as success stories. Our real success is the perseverance that has allowed us stability even in tumultuous times.

If there are lessons to be learned, I am convinced that anyone in this position must never take things personally. Dealing with ambiguity and multiple agendas are a way of life in our university environment. I have learned that is it my job to provide a vision but it will work much better if we see our work as a shared vision. Perhaps the most difficult learning is that every day you are dealing with people's lives - their hopes, their dreams, their pain, and their passion. I must never lose sight of my need to treat everyone with dignity and respect and, at times, when you least feel it, you must always be gracious and civil. I am always encouraged by the forgiving nature of people and their willingness to let you make a mistake if you will just admit the mistake is yours. In the final analysis, I am always grateful for friends who have the courage to say to me, "You could have done that better" or "You may want to think about how you do that next time." It is only with advisors who are loyal and who care about you that you can survive in this lonely business called leadership.

\section{An Associate Dean's Story}

In my mind, leadership does not just happen one day. A record of leadership responsibilities tends to accumulate over one's career. In my case, it involved leadership roles in various groups and organizations from the personal to the national level. My formal leadership role in higher education, however, began with a short stint as Interim Associate Dean in the College of Education in the spring of 1998. After that initial experience, I returned to my faculty role. Three years later, the Associate Dean position was once again vacant and the call came for an interim Associate Dean. I forwarded my name as a candidate and was selected. I have served in that interim position for 3 years.

As I reflect on my journey in leadership, I can clearly identify two role models. One was early in my journey, the other more recent. The first mentor I came upon during my master's degree work. I was taking a "Gifted Education" course with a professor I admired and we were using a book she wrote. At the end of the semester, I asked her to autograph the book for me and she wrote, "You are a female with exceptional abilities. Don't settle for second best. Education needs your mind and special personality." Her words had a striking impact on me. This woman who I admired for her intelligence, strength, and emotion had validated me. It was because of her words that I chose to continue on and get my Ph.D. She became my doctoral advisor, mentor, and friend.

My second mentor is the dean with whom I currently work. She exemplifies the ideal of a mentor. To begin, she supported my move to the office of Associate Dean by helping me to feel confident in my ability to do the job. In the 3 years that I have served in that role, she has given frequently of her time to mentor and support me. She has provided incredible opportunities for growth and leadership. In a work world that can be tumultuous and controversial, she continually models strength and integrity. She models the type of advocacy that supports each individual within our College. We talk openly and frequently about all aspects of the College and she makes me feel valued. Frequently, she prefaces a discussion with the words, "This is another lesson in deaning..." and goes on to share something that has happened. Her unwavering trust and unequivocal support have made my journey into administration a positive and constructive learning experience for me.

The greatest challenge in my current position lies in the union structure in which I work. The Dean and the Associate Dean are the only two "supervisors" in the entire College. Our chairs are elected faculty, but they hold no supervisory powers. Our strong union presence creates an adversarial relationship between faculty and administration. I truly believe that these two groups need to work together to create rigorous, cohesive, and professional programs. Many times we seem to spend more time running roadblocks than we do moving forward. Such waste of time, talent, and energy is very frustrating and challenging to me. 
Successes in the role of an Associate Dean tend to come in small, unspectacular ways. Working with new faculty, solving student issues, and dealing with building issues all bring with them rewards that would go unnoticed by many. One of the greatest benefits of sitting in the Associate Dean's role, however, is the ability to work with diverse faculty and programs across the College. As a result of my work with faculty in several departments, we recently received a large federal grant to facilitate new student teaching approaches and mentoring programs for our new teachers. This grant is one of the best success stories for me personally, and for the college as a whole.

\section{A Department Chair's Story}

One does not awaken on a particular morning as a "leader" anymore than one arrives suddenly at middle age. I am just as surprised at being perceived as a leader as I am by looking in the mirror at my own wrinkles! The former crept up on me unawares and certainly was unplanned! The latter crept up as well despite its inevitability. The leadership journey, however uncharted, probably began in the womb (according to most child development specialists at any rate). My mother integrated the South Carolina League of Women Voters and participated at lunch counter sit-ins during the years of racial unrest in the south. She made plans and carried them out, pushed ahead in arenas of her choosing, and stood out among her peers. Leadership was modeled, not taught. It was expected, not negotiated. I have always assumed that women are leaders whether they are in the forefront or relegated to the back rooms.

But women of my generation (born in the 40s) are expected to maintain somewhat of a demure presence, to be nurturers and negotiators, to accept our place under the glass ceilings and within our homes. Therefore, the greatest challenge for me today as a department chairperson is to act the part! I feel the need to make everybody happy, to accept others' responsibilities rather than delegate, to lick my wounds in private. While I find it challenging to mediate student/faculty issues, I enjoy the opportunity to bring two factions together and find solutions to differences both had deemed irreconcilable. However, it is much more difficult for me to confront a faculty member about a situation concerning their pedagogy or work ethic. At this strongly unionized institution, department chairs have no supervisory authority, so any conversations I have with faculty are perceived as just that and, at times, all that results is hurt or blame rather than redirected energies. An additional challenge is the continuous treading of political and traditional waters in an attempt to maintain footing (i.e., schedule next semester's classes, advise students, teach, etc.) rather than being allowed to jump off into the deep end and swim into open waters (i.e., create new ways of packaging course content, new field experiences, new collaborations, new research endeavors).

Ironically, in retrospect an interesting success story was also one of my biggest challenges. It occurred when the entire department of eight faculty very unexpectedly confronted me at a meeting. While the proverbial "straw" was my having invited the Dean to a meeting 2 days prior, this meeting evolved into an opportunity to bring to the table 2 years' worth of woes! For several hours I listened to one after the other faculty list their grievances against my leadership (having invited it after realizing that there was "more to the story" than the Dean's visit). While it was one of the most painful experiences of my academic career, it was amazingly constructive for me. (Please be aware however, that this statement can be made only after 3 months of quietly licking my wounds).

Lessons are sometimes learned best when they make the deepest emotional dents on our psyches. I have learned that the less I accept as a personal onus, the healthier I am. Of course, it follows that I should not be personally accepting accolades for department accomplishments either. I have learned that I have a stronger set of shoulders than I had thought-perhaps because they hadn't previously been forced to bear this tonnage. I have learned that ethical behavior is the only way to stay above the fray and withstand accusations of erroneous words or actions. I have learned that competent clerical assistance is the most essential component of a leader's workforce. I have learned that teaching is what keeps me healthy and that, regardless of any future leadership positions I might hold in higher education, I must continue to teach! 


\section{A Clinical Experience Director's Story}

My leadership journey began as a member of a large family, then as a high school and college athlete, and later as a coach and teacher. Each of those experiences added value and have impacted any leadership qualities I have today. Currently, I am the Director of the Office of Clinical Experiences in a large college of education in the Midwest. Our office is responsible for building relationships with area schools and securing field and student teaching placements for several hundred students each semester.

I think I have been very fortunate to have had a number of very significant mentors throughout my lifetime. The first being my mom, she was an incredible woman who overcame many obstacles throughout her life - she instilled in me the strength of perseverance, a strong sense of commitment, and a healthy work ethic. In addition to a strong foundation (which I did not realize I had until it was too late to thank her), I am fortunate to have had strong mentor in the chair of my doctoral dissertation committee. This person believed in me. I know that sounds like a cliché, but I did not believe in myself very much and was not sure that I had what it took to complete the doctoral program or truly be a leader in education. Upon completing my dissertation she said to me, "Someday you're going to be a Dean and a President at a University, and I'll say I knew you when." I, of course, thought she was nuts. The point is, her believing in me allowed me to think about things I had not thought about before. After completing my doctoral program I was fortunate to walk into the office of another incredible woman who has mentored me for the past 5 years - my current dean in the College of Education. These women were from the same mold, they both are strong women who do not back down from any challenge. I have learned a tremendous amount from our current dean and I will continue to do so. Her mentoring has been extremely valuable as I continue to navigate an environment that seems to put up road blocks and barricades at every corner.

My greatest challenge in my current position is the politics and the union structure of our University. There are incredible faculty members here, but the ability to change for some is quite difficult. Sensing what needs to be done and then moving in that direction seems to take an incredible amount of time. Since our office is a relatively new one, the controversy of its development is constantly questioned. The need for it is well-documented, the workload is at times overwhelming and one that no one else wants; yet everyone wants to tell you how to do what it is you are supposed to be doing. Another challenge related to our current structure is the lack of authority.

My best success story-I have learned a tremendous amount along the journey and I continue to learn. One lesson that I am continually learning and working on is balance. My ability to balance my personal and professional life is much different than others because we all are at different places in our lives and the demands from family and friends may be very different. When I become overwhelmed with what there is to do, or I feel like I'm failing those in my personal life who need me, I remember that if I dropped dead today the University would replace me, but my family would always remember me and how they remember me is what is important. I will never have enough time to spend with them (unless I win the Powerball), but I do have control of the time I do have to spend with them.

I have also learned that it is very important to surround yourself with people who are better than you are and who can strengthen your weaknesses. I have an incredible staff-much of it I fell into, but they have strengths that I do not possess. Without them, our office would not be as successful, nor would I. However, probably the most important thing to always remember is to find something to laugh about. All the clichés are true, "laughter is the best medicine." When things are stressful, if you can find something funny in the situation, you will always survive.

\section{An Assistant Superintendent's Story}

I did not know a female high school principal until I became one. My mentors were all male secondary principals and superintendents. They encouraged me to enter the male-dominated career of secondary and district level K-12 administration, and I watched and listened and learned much from them, but also often learned how not to lead. Those beginning years, I would attend regional and state secondary administrator meetings and would be the only or one of a handful of female high school principals. 
In 1984, I became a high school assistant principal and then a principal in four different Minnesota high schools over 13 years. While many saw the role of assistant principal as a disciplinarian and a less than desirable stepping stone to a principalship, I felt like I was "making a difference." The challenge for me was to try to find out why a student was acting out and to assist them in making changes to facilitate their success. The 9 years I spent as principal in a large high school, however, were the most exciting and challenging years of my career. I believe the principalship is an art, and the leadership opportunities to make a different in students' lives are vast and profound. My administrative style evolved into a highly collaborative approach, utilizing a parent/staff site council, student advisory groups, faculty committees, etc. I also utilized what I like to call "creative finance." I would not let money be an excuse, if teachers felt they needed something, and I believed it would improve instruction, I would find a way to provide the needed funds. During my tenure, major improvements were made to the building, advanced placement and college level classes were added to the curriculum, and special education students moved from pull out to mainstream classrooms.

In 1997, the superintendent of my school district of 11,000 students invited me to accept a new position working with special projects. I became the Assistant Superintendent/Special Projects and began working with community and post-secondary partnerships and federal grant requisition. During the last 6 years I have had the opportunity to work with a plethora of programs involving community partnerships and federal grants, including professional development schools, programs for at risk students, an elementary counseling program, a community partnership for safe schools and healthy students, and a health careers internship program. To date, the special projects office has been awarded 20 million dollars and employs over 70 staff throughout the school district.

My partnership activities with post-secondary have also lead to the opportunity to do adjunct teaching in educational administration and leadership programs. My greatest challenge now is to be a mentor to these future educational leaders and reinforce the skills and talents that make thoughtful, creative leaders.

\section{Summary}

Reflecting upon leadership, these five women appear to have several commonalities in their leadership journey. First, four of the five suggest that their mother was a strong role model. Yet, when pressed to think about a specific mentor, most often the women identified a professor, a dean, or a dissertation chair- "someone who made them believe in themselves." Second, the context in which each woman works seems to play a significant role in their leadership. Descriptors such as "acting the part," "not settling for second best," "making me feel valued, "not backing away from a challenge," and "learning to delegate" are all listed as challenges in current leadership roles. Third, the greatest challenge in their current position differs according to the position; yet, even here there are commonalities. One woman states that knowing you are responsible for what happens "on your watch" is a great challenge. Three of the leaders identified working in a union structure as a challenge. One talked of the "continuous treading of political and traditional waters ... rather than being allowed to jump off into the deep end and swim into open waters" as a way to think of additional challenges in her leadership role. In each case, the identity of partnerships seemed significant for these women leaders as they reflected on their role (s).

Examining the leadership principles that apply in a specific context seems to give rise to the following for the five women:

1. Setting goals and establishing a plan to reach the goal.

2. Establishing a vision.

3. Overcoming barriers and roadblocks.

4. Maintaining ethical behavior.

5. Having competent clerical assistance.

6. Remembering that laugher is the best medicine.

7. Acknowledging the importance of making a difference in students' lives.

8. Utilizing creative finance and finding ways to provide needed funds.

9. Being willing to take risks.

10. Accepting the responsibility of being a mentor for future leaders. 
In conclusion, the voices are diverse as these women reflect on their leadership journeys but the stories seem to affirm that the transformational leader inspires others to excel, gives consideration to others, and asks people to think in new ways. These five women exemplify these characteristics.

\section{References}

1. Bowman, L., \& Deal, T. E. (2001). Leading with soul. San Francisco, CA: Jossey- Bass.

2. $\quad$ DePree, M. (1999). Leadership is an art. New York: Dell Publishing.

3. $\quad$ Gilligan, C. (1982). In a different voice. Cambridge, MA: Harvard University Press.

4. Kouzes, J. M., \& Posner, B. Z. (1987). The leadership challenge. San Francisco, CA: Jossey-Bass.

5. Moxley, R. (1999). Leadership and spirit: Breathing new vitality into individuals and organizations. San Francisco, CA: Jossey-Bass.

6. Sample, S. (2002). The contrarian's guide to leadership. San Francisco, CA: Jossey-Bass.

7. Women in higher education. (2003 March). Take big career risks, Shalala learned as a rookie. Madison, WI: Author.

8. Woolf, V. (1929). A room of one's own. New York: Harcourt, Brace, and World.

9. Zimpher, N. L. (1995). What deans do: A reflection on reflection. In L. S. Bowen (Ed.), The wizard of odds: Leadership journeys of education deans. Washington, DC: AACTE.

Notes 